\title{
A Stakeholder Relationship Framework for a Sustainable and Effective Business Strategy
}

\author{
Silvia Vernizzi ${ }^{1}$, Andrea Beretta Zanoni ${ }^{1}$, Sara Moggi ${ }^{1} \&$ Silvia Cantele ${ }^{1}$ \\ ${ }^{1}$ Business Administration Department, University of Verona, Verona, Italy \\ Correspondence: Silvia Vernizzi, Business Administration Department, University of Verona, Verona, Italy. \\ E-mail: silvia.vernizzi@univr.it
}

Received: December 20, 2018

Accepted: January 22, 2019

Online Published: February 6, 2019

doi:10.5539/ijbm.v14n3p1

URL: https://doi.org/10.5539/ijbm.v14n3p1

\begin{abstract}
Several studies have underlined the importance of including sustainability issues in business models, yet little is known on ways in which to embed stakeholders' influence in defining and executing firm strategies. In light of this gap, this study inductively develops a framework for stakeholder relationship assessment, which suggests methods to evaluate relationships between the firm and stakeholders, with a dual aim: to embed more sustainable strategies in business models and to make strategy execution more effective and less risky. In doing so, a case study is conducted on Science Lab owing to the multiple stakes of its stakeholders. It presents a unique example on how stakeholder relationships were evaluated for making a strategic decision that, in this case, was whether to close (or not) the organization. This study contributes to the existing literature stressing the role of stakeholders in influencing strategy realization and proposes a useful managerial tool to improve the effectiveness of strategy execution through a better understanding of the role played by each stakeholder.
\end{abstract}

Keywords: business model, strategic functionality, stakeholder salience, strategy execution

\section{Introduction}

In a competitive context, every firm, bar none, needs a strategy. In such a context, a firm's' achievement of goals does not only depend on the way it conducts its activities but also, and most importantly, on the way it does so compared with its competitors. Strategy is about "looking outside" the firm and trying to understand how to continuously reshape its business model to capitalize on opportunities and to prevent threats (Doz \& Kosonen, 2010; Weber \& Tarba, 2014).

Over the past decades, globalization, technology convergence, and innovation have made the economic environment increasingly complex. Amid this complexity, the topic of sustainability (Amini \& Bienstock, 2014; Baumgartner \& Rauter, 2017; Lozano et al., 2015; World Commission on Environment and Development, 1987) has gathered momentum and has become a central issue in companies' boardrooms (Baumgartner, 2014). Several frameworks rooted in the strategic management debate propose embedding sustainability in corporate strategy (Baumgartner, 2014; Baumgartner \& Rauter, 2017; Engert \& Baumgartner, 2016; Engert et al., 2016; Rauter, Jonker, \& Baumgartner, 2017). In addition, along with reporting and disclosure to stakeholders, we are experiencing several attempts to integrate strategy and sustainability (Adams, 2015; Beattie \& Smith, 2013; International Integrated Reporting Council, 2013, McKinsey \& Company, 2014). Accordingly, the set of relationships a firm has built with its stakeholders must be considered a pivotal item in the strategizing process (Freeman, 1984; Mitchell, Bradley, \& Donna, 1997).

In the overall strategic planning process, the business model is the point of contact between a firm and stakeholders (Baden-Fuller \& Morgan, 2010; Chesbrough, 2010; Zott \& Amit, 2008). In this sense, the sustainable business model (SBM) incorporates the three dimensions of sustainability, considers a wide range of stakeholder interests and provides connections among several business items, such as between strategy and sustainability (Bocken, Short, Rana, \& Evans, 2014).

Despite the literature presenting extensive consideration on the relationship between stakeholders and reporting, little is known until date regarding the role the business model plays as a tool to manage relationships with stakeholders (Bocken et al., 2014). To fill this gap, this study presents a framework to assess the relationships between the firm and stakeholders to embed sustainable strategies in the business model and to make strategy 
execution more effective (and less risky). Therefore, we focus on the following research questions:

How should a firm consider stakeholder relationships to make its strategies more sustainable?

How should a firm consider stakeholders to improve strategy effectiveness?

To address the research aims, we considered performing a case study the best option to explore an under-researched issue. The case of ScienceLab (a pseudonym) center was selected because it presents a unique example on how stakeholder relationships were evaluated to take a strategic decision that, in this case, was whether to close (or not) the center. ScienceLab is a research center of a big pharmaceutical company (hereafter, BigPharma) and is a leader in cancer research, with more than 400 employees and numerous applied research studies of concrete use in cancer drug formulation. For the case study, data were collected over a one-year period through participant observation (Denzin, 1978) conducted by two researchers, who were involved directly in the stakeholder analysis and framework development. In addition, semi-structured and structured interviews permitted exploring and assessing the two dimensions of the proposed framework.

Starting from Mitchell et al.'s (1997) study that defined stakeholders' salience considering their three main attributes (i.e., power, legitimacy, and urgency), this study suggests a further dimension of analysis to see 'who really counts' (Freeman, 1984: 91). This additional dimension should be intended as the role played by each stakeholder in strategy implementation and realization, termed strategic functionality. Through coupling the two levels of analysis - level of salience (i.e., behavioral attitude of stakeholders) and of strategic functionality (i.e., role played by each stakeholder in strategy implementation-realization) - the analysis of the ScienceLab case increases the understanding on how stakeholders could influence a firm's strategy realization and on how managers could balance divergent stakes when making decisions. Proposing a stakeholder relationship framework, the study provides a managerial tool, valuable to drive strategy implementation effectively through a better thoughtful of the role played by each group of stakeholders.

The rest of the article is organized as follows. Section 2 first presents a review of the theoretical background on the strategy-sustainability relationship and then of the salience approach to the stakeholder theory employed to build the framework. Section 3 provides insights on the case study selection, data gathering, and analysis of the wide range of data collected. Section 4 describes the phases to implement the framework and its functioning in the real context of the selected case. Finally, Section 5 presents a discussion and concluding remarks on the main insights derived from the framework development and application.

\section{Theoretical Background}

\subsection{Business Strategy and Sustainability}

Among the different issues stemming from the strategic discourse, the analysis of the relationship between business strategy and sustainability has become a key question for academics, business managers, and policy makers. Within the borders of this research field, several scholars have discussed how firms can act strategically and successfully in a sustainable way.

Numerous studies underline how the foundation of sustainability activities in the organization culture is an essential precondition for business success (Baumgartner, 2009; Burke \& Logsdon, 1996; Dentchev, 2004; Lankoski, 2007). Following this "cultural approach," other researchers highlight how corporate sustainability decisions should be rooted in a sustainability-related vision (Jin \& Bai, 2011; Stead \& Stead, 2000) and mission statement (i.e., two of the core concepts of any business strategy), emphasizing how, before developing any strategies, the extent to which sustainability is part of the vision and mission should be clarified.

Moving from strategy formulation to implementation, other scholars discuss the corporate sustainability strategy implementation issue, focusing on the factors required to translate a sustainability strategy into successful execution, related to organizational structure, organizational culture, leadership, management control, employee motivation, and communication (Engert \& Baumgartner, 2016). Baumgartner and Rauter (2016) analyze opportunities, benefits, risks, and trade-off associated with the implementation of corporate sustainability within strategy formulation and execution. Adopting three different and complementary dimensions (i.e., process, content, and context of the strategy) Baumgartner and Rauter (2017) support successful integration of sustainability issues into corporate activities and strategies. The manner in which responsibility (sustainability side) and market opportunity (strategy side) can be merged has also attracted attention, highlighting how sustainable development can be a source of value creation both for company and for society (McWilliams \& Siegel, 2011).

Among the different studies contributing to the strategy-sustainability debate, the business model issue has gathered momentum. In this context, some studies, both in academia (Duarte et al., 2008; Hemingway \& 
Maclagan, 2004) and in practice (McKinsey \& Company, 2014) examine the relevance of business models for the strategy-sustainability formulation and implementation issue, paying attention to how the business model should be designed to include sustainability items.

The centrality of the business model in the strategy-sustainability relationship finds its reasons in the business model definition and in the relevance of the business model concept in company activities and processes. Scholars agree that the organization's business model can be defined as the way in which the organization is able to profit through the provision of products and/or services (Rauter et al., 2017) and it spans industry and firm boundaries (Amit \& Zott, 2001). If correctly employed and comprehensive of its dimensions, the business model also helps to identify the features of company relationships (both internal and external) (Boons \& Lùdeke Freund, 2013; Osterwalder, Pigneur, \& Tucci, 2005). Although the concept of the business model is widespread in practice and in strategic theory (Ghaziani \& Ventresca, 2005; Lambert \& Davidson, 2013; Magretta, 2002; Zott, Amit, \& Massa, 2011), it lacks a single, comprehensive definition (Zott et al., 2011).

For fulfilling the aims of this study and adopting the perspective of linking the business model to the dynamics of strategy realization and implementation (Richardson, 2008), we define the business model as the set of choices related to the way in which a firm decides to implement its activities that generate value. These choices encompass several aspects of firm life, such as (i) business portfolio (Abell, 1980); (ii) positioning in each business/businesses (Bowman, 2008; Fiegenbaum, Hart, \& Schendel, 1996; Håkansson \& Sneotha, 1995; McNamara, Deephouse, \& Luce, 2003; Porter, 1980; Ries \& Trout, 2001); and (iii) structural and organizational architecture of the firm, intended as the set of choices related to its resources, relationships, activities, policies, ownership, governance, and so forth.

Since a business model, with its different aspects and definitions, is at the core of business activity (Rauter et al., 2017), integrating sustainability in the business model and its strategy is an essential issue for top management. In other words, the reconfiguration of the business model toward a sustainability direction may be considered a prerequisite "for holding onto market positions and sustaining revenues" (Simanis \& Hart, 2009, p. 83). Starting from these considerations, some scholars attempt to determine the conditions required when reshaping business models into business models for sustainability (Rauter et al., 2017). How business models should be adapted to embed sustainable issues continues to be debated (Bocken et al., 2014; Chesbrough, 2010; Zott et al., 2011). In particular, starting from the concept of business model innovation (Chesbrough, 2007, 2010), scholars analyze the reasons for changing and rebalancing (existing and future) business models with respect to sustainability (Rauter et al., 2017).

Recently, the literature has underlined the need to span the boundaries of SBM considering the stakeholder groups able to influence, and be influenced by, organizational actions. Accordingly, SBM should be designed considering stakeholders' claims and requests to make business strategy more effective (Bocken et al., 2014) and related to the balance of the essential relationships of the firm with its stakeholders (Baumgartner, 2010, 2014). In other words, strategizing should also take into account stakeholders, their claims, and their ability to influence (positively or negatively) a firm's strategy realization.

In the design of a business model, stakeholders and their attributes become a core aspect and no choice made by the firm can overlook its stakeholder relationships. For instance, the choice of business positioning needs to take into account clients, suppliers, and competitors, whereas choices related to structural and organizational architecture of the firm need to consider relationships with stakeholder groups, such as investors, human resources, trade unions, and external communities.

The centrality of stakeholders in the business model concept leads to the fact that stakeholders play a central role both in strategy formulation (the process of making strategic choices) and in the process, even more complex, of strategy execution (the process of implementing strategic choices). The adoption of a model considering these aspects as well should help enterprises avoid strategic inertia and enhance company resilience. Strategic inertia can be defined as the tendency of organizations to maintain the status quo and resist strategic renewal outside the frame of current strategies and current stakeholder relationship settings (Huff, Huff, \& Thomas, 2007). In this sense, the identification of key stakeholders (Clarkson, 1995; Freeman, 1984; 1994; Windsor, 1992), the definition of the nature of firm-stakeholder relationships, and the comprehension of the way in which they can influence the strategy are central points of every company boardroom.

\subsection{Stakeholder Salience and Strategic Functionality Assessment}

Over the past decades, the debate around who "really counts" as a stakeholder has been of great interest within the sustainability discourse (Clarkson, 1995; Freeman, 1994). Several scholars suggest different definitions of the term stakeholder. Starting from Freeman's classical broad definition $(1984$, p. 46), which identifies a 
stakeholder as "any group or individual who can affect or is affected by the achievement of the organization's objectives," the literature offers several interpretations. In more detail, narrow views of the stakeholder are based on the practical reality of limited resources and limited capability of managers of dealing with different constraints (Mitchell et al., 1997). For example, some scholars define stakeholders in terms of their necessity to the firm's survival (Bowie, 1988; Näsi, 1995), whereas others consider stakeholders as contractors or participants in an exchange relationship with the firm (Cornell \& Shapiro, 1987).

In this study, according to Clarkson (1995) and his narrow definition of a stakeholder, we consider stakeholders as those who have placed something at risk in relationship with the firm-something that could vary in nature, that is, be of economic nature or financial nature but is also intangible in nature. Defining the meaning of stakeholder is the first step in the stakeholder relationship assessment. The next step is to map the organization's stakeholder groups and their needs, and determine ways to strategically respond to their claims. Among the different tools that have always played a significant role in strategic theory and in strategic analysis, maps and matrixes play a central role (Faulkner \& Bowmann, 1995, Hofer \& Schendel, 1978). Such tools enable the analyst to describe and schematize phenomena, providing a sufficiently complete picture of the problem (Solinas \& Vernizzi, 2011). The advantage of these tools is the immediacy of the description they provide.

The most delicate aspect of preparing any map is identifying its significant dimensions. In designing the map, it is possible to identify different dimensions within the several types of firm-stakeholder relationships. For example, stakeholders may be classified into "internal" and "external" or they can be grouped according to the nature of the stake they hold in a firm's activities (e.g., economic, financial, and psychological) or, moreover, they can be classified depending on the time manifestation of their interests. In general, by using a map, it is possible to group stakeholders into homogeneous classes, with reference to specific dimensions considered significant (Faulkner \& Bowmann, 1995). Notably, the choice of the dimensions depends on the specific needs of the analysis and since the needs can change over time, it cannot be a prearranged choice.

Based on these premises, to select the relevant dimensions of the stakeholder relationship framework we start from Mitchell et al.'s (1997) study that defines stakeholder salience on the base of the ownership of three main attributes (i.e., power, legitimacy, and urgency). According to Mitchell et al. (1997), the analysis of the existing relationship between a firm and stakeholders can be viewed from three different perspectives traceable according to these three attributes. According to Suchman (1995, p. 574), "Legitimacy is a generalized perception or assumption that the actions of an entity are desirable, proper, or appropriate within some socially constructed system of norms, values, beliefs, and definitions." Legitimacy allows identifying the nature of a relationship and grasping its core elements; power and urgency reveal the relationship's functioning mechanisms. That is, legitimacy is a factor that allows management to determine whether an entity is a "stakeholder" of the firm and its intention in "investing" in the firm in different ways (e.g., economic, financial, and psychological). Conversely, this stakeholder cannot be voluntary influenced by the firm actions and its "stake" is the risk involved in the firm's actions, such as a pollution risk for the community.

The second attribute, "power," defines the capability of imposing one's own will within the relationship. Power depends, at least in part, on legitimacy, but its origins and its expressions are relatively complex. Some stakeholders have more power than others; rather, others have no power at all. The reasons behind this difference can be traced to different factors, such as the access to information media, knowledge of the firm's economic processes, and support of other institutions.

The third attribute is "urgency," defined as the coexistence of two conditions: the time sensitivity of the relationship and the importance of the relationship to the stakeholder. In this sense, urgency inserts in the relationship the time constraint that is essentially not strictly connected to the other two variables (legitimacy and power).

Starting from the three perspectives of analysis (legitimacy, power, and urgency), it is possible to obtain an overview of the nature of the relationships existing among the firm and its stakeholders. Considering the three elements as a whole, this study views this as the first dimension of the "strategic relationship framework": the "salience dimension," that identifies and measures the level of reactivity that each stakeholder has toward the evolution of the relationship with the firm.

The second dimension of the stakeholder relationship framework is the strategic relevance of the relationship, intended as the role played by each stakeholder in the process of strategy realization. In other words, it means to understand the extent to which, and the way in which, stakeholders can influence the process of firm strategy formulation and implementation. Moving from the main literature on strategy and SBM, this second dimension of framework refers to has some pivotal factors. First, this dimension could be shaped according to the 
stakeholders' influence on the general strategy and the choices at corporate level (e.g., governance and ownership). Further, economic and financial choices (e.g., investments, costs, and revenues) are taken into account together with the business portfolio choices and the decisions about the positioning to have in each business. Another pivotal issue to consider in defining the strategic dimension of the framework embeds the several aspects related to activities and processes (e.g., human resources policies, trade union relationships, operating mechanisms, and decision processes), coupled with the social effects that these actions could have on stakeholders, such as the local community and the environment.

Each aforementioned factor responds to specific "stakes," and different stakeholder groups can have a specific, different role in relation to each of them. Moving from the summarized literature, the combination of the two dimensions of "strategic salience" and "strategic functionality" drives the purpose of the following the "stakeholder relationship framework" (see Figure 1).

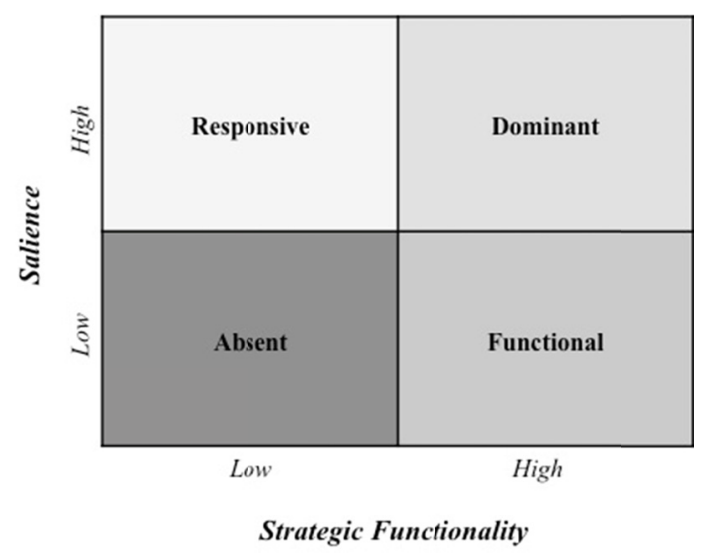

Figure 1. Stakeholder relationship framework

According to the position within the matrix, we suggest the identification of four different categories of stakeholders:

1) Dominant stakeholder: high strategic salience and high strategic functionality;

2) Absent stakeholder: low salience and low strategic functionality;

3) Responsive stakeholder: high reactivity and low strategic functionality;

4) Functional stakeholder: high strategic functionality and low reactivity.

To verify the applicability of this framework, the following sections introduce how the nodel assumes different nuances and managerial implications in practice, broadening the traditional boundaries of business model studies (Bocken et al., 2014).

\section{Methodology}

Eisenhardt, Graebner, and Sonenshein (2016) suggest inductive approaches, based on in-depth case studies, to create innovative theories and frameworks contributing to address societal changes. Accordingly, this study contributes to inductive studies proposing new models and interpretation on stakeholders' theories, as summarized in Figure 2. 


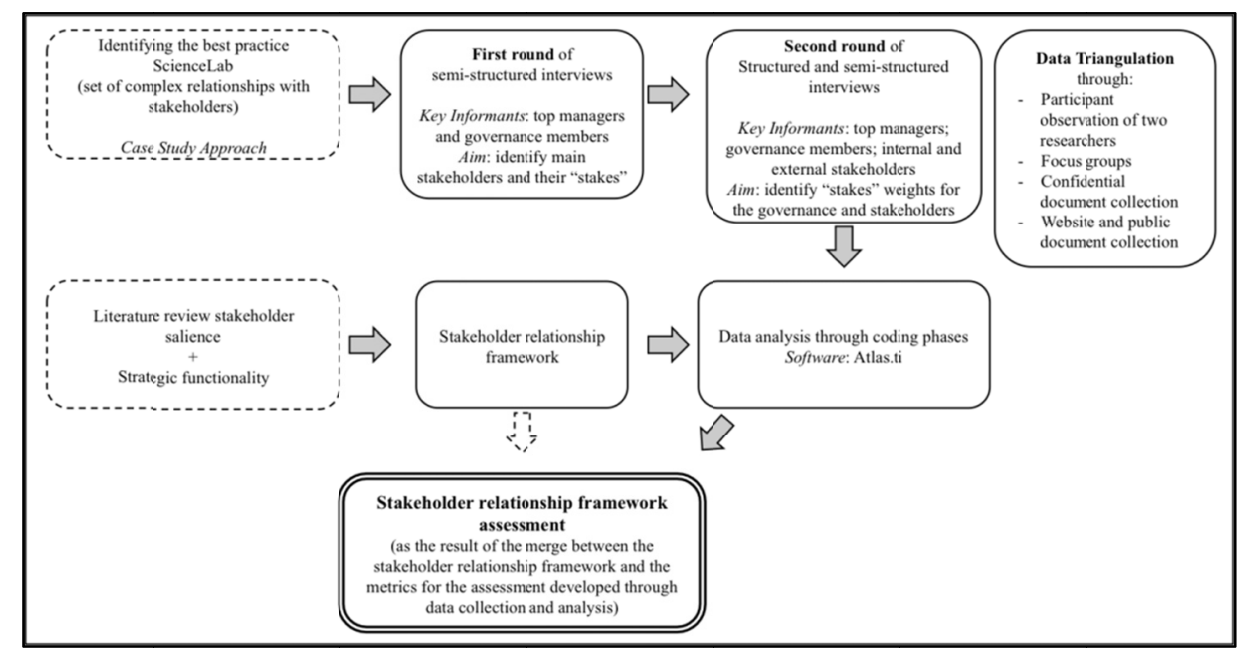

Figure 2. Inductive research approach toward the stakeholder relationship framework assessment

Following this encouragement, this study moves from the case study methodology that is also widely employed in management studies (Berg, 2009; Eisenhardt, 1989) because of its ability to provide qualitative evaluations on company actions and strategies. ScienceLab was selected since it presents a unique example of a set of complex relationships with stakeholders to manage owing to several issues on interests that sometimes diverge. The center was owned by BigPharma, a leader in the sector that invested in the center to increase its impact in the research and development on cancer. ScienceLab had more than 400 employees; it still represents a reference point for the global scientific community on cancer research.

Owing to company reorganization, BigPharma had to consider closing the research center to avoid duplicating the functions and costs. This hypothesis steered the company to consider all the effects-in particular, social and economic _ owing to this possible choice and drives the need to map and assess the effects on the stakeholder groups that would have been affected by this decision. Two of the authors were involved in the process of stakeholder analysis and framework development, providing firsthand data through a year of active participant observation (Denzin, 1978). Since the in-depth approach of a single case study requires multiple sources of data (Yin, 1984), the hermeneutic unit of this inductive study embeds information emerging from the triangulation of different sources (Patton, 2002), such as participant observations, semi-structured/structured interviews, focus groups, and document analysis.

The possibility to enter the organization permitted the gathering of valuable and highly accountable data (Sherman, 2001). The direct experience of the participants was shared with the other researchers by personal notes transcribed electronically. Further data were collected through two rounds of interviews to support the inductive approach in building and designing the assessment of the two dimensions in the proposed framework (see Figure 1).

The first round comprised semi-structured interviews of the company's top managers and governance members that were carried out to identify ScienceLab's key stakeholders and the main "stakes" they had in the center and in BigPharma. In addition, data were triangulated with confidential documents and public reports available on these organizations' websites to increase their reliability. Data collected were analyzed to define: (i) the stakeholder map and the main group of stakeholders in this map and (ii) the aspects to be considered in assessing stakeholder salience and strategic functionality.

In the second round of interviews, the range of informants was enlarged considering also internal and external stakeholders identified through the snowball sampling technique (Patton, 2002) during the first round of interviews and the document analysis. The researchers followed a mixed approach in conducting the interviews, considering both semi-structured and structured questions. The interview framework was different for the top managers and stakeholders because of the different aims of these interviews. The managers were asked to identify the weight of each factor defined by the first round of interview. For instance, considering stakeholder salience as whole $(100 \%)$, they were asked to attribute the weight (in percentage) of each factor, such as Time Sensitivity equals to the $20 \%$ and Exit costs to the $30 \%$. On the other hand, for the stakeholders, the interview framework embedded a question with closed answers, requesting them to rank (from 1 to 5) the importance of the factors on stakeholder relationships identified in the first round of interviews. In addition, the opening 
questions provided information on the reason for the answers to the closed questions. When possible, stakeholders' opinions were collected through focus groups composed of only participants of the same group of interest, such as employees and financiers. This approach provides the consonance effect and avoids contrast in the group discussions, providing results that should be considered the unique voice of a stakeholder group (Moggi, 2017).

The analysis and the related several coding phases were supported by a rich hermeneutic unit managed through Atlas.ti 7.0 software (ATLAS.ti Scientific Software Development GmbH, Berlin, Germany), a well-known support for qualitative studies.

\section{Stakeholder Relationship Framework Assessment}

For identifying the nature of the relationships that a firm has built with its stakeholders and analyzing the role played by each of these in the process of strategy formulation and implementation, this study suggests a method composed of three main steps as represented in Figure 3.

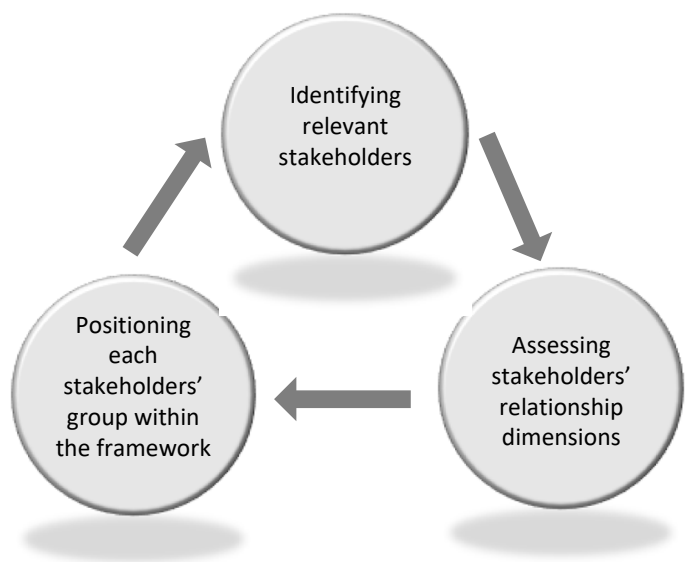

Figure 3. Process of strategy implementation through stakeholder analysis

The following subsections provide insights on how this framework could be managed to embed relationships with stakeholders in an organization's strategy, using ScienceLab as the area of assessment of the proposed framework.

\subsection{Identifying Relevant Stakeholders}

Drawing the map of firm-stakeholder relationships is the first step toward identifying the main group that influences, and could be influenced by, the firm. At this point, we can exclude from the framework boundaries the stakeholder that does not have a stake in ScienceLab (and its owner, BigPharma) and is not therefore strategically important in the design of its business model. Following the extensive use that the presented strategic literature and practice have made of maps and matrixes, our model starts with drawing a "stakeholder relationship map" aimed at analyzing and evaluating the nature of the firm-stakeholder relationships and the role played by each stakeholder group in strategy implementation. Moving from theory to practice, according to the aforementioned definition, we try to identify relevant stakeholders for ScienceLab. From the first round of semi-structured interviews with the managers and governance members and internal document analysis, we identify five relevant stakeholder groups that, in different ways, have a stake in the relationship with the ScienceLab and consequently with BigPharma:

1) Shareholders: They have made economic investments in BigPharma, and they are interested in maintaining company reputation and the trust from the community.

2) Human resources: They rely on ScienceLab to fulfill their personal ambitions and economic safety.

3) Labor Unions: These have political interests in the relationship with the firm that are critical owing to the exposure of the pharmaceutical center to media and public information.

4) Scientific community: It has high expectations from the relationship because of the relevance of the oncology research carried out by the center.

5) Financers: These include entities who have made financial investments in supporting ScienceLab activities, such as the region (by grants) and banks (by loans). 
All these stakeholder groups have placed something at risk in the relationship with ScienceLab and BigPharma. They hold different, and in some circumstances, divergent interests that the firm's management has to consider.

\subsection{Assessing Stakeholder Relationship Dimensions}

The second step in defining stakeholder relationships as suggested by the framework consists of assessing the relevance of the factors that define the two dimensions of the framework. The factors were identified through coding of the data derived from the round of interviews with top management and governance (first round) and can be summarized as follows for the salience and strategic functionality dimensions:

Table 1. Factors for stakeholder relationships' dimensions

\begin{tabular}{ll}
\hline Salience dimension factors & Strategic functionality dimension factors \\
\hline Level of expectations & Choices at corporate level \\
Exit cost levels & Economic and financial choices \\
Symbolic relevance of the relationship & Business portfolio choices \\
Time sensitivity & Positioning choices in each business \\
Stakeholder power & Choices related to activities and processes \\
& Social choices \\
\hline
\end{tabular}

Starting from these factors, we investigate how to find a relevant measure. In the second round of interviews, the top managers were asked to attribute a value that measures the relevance of each factor for the two stakeholder relationship dimensions. Added to this, we assign a weight to each factor to highlight its specific relevance within the defined group of factors included in each of the dimensions (salience and strategic functionality).

Simultaneously, in this second round of interviews we asked the main stakeholder groups to attribute an importance score to each factor, ranging from 1 (low) to 5 (high). In more detail, we consider a representative for each stakeholder group and by means of semi-structured and structured interviews and focus groups purposely appointed, we collect all the information necessary to obtain insights on the firm-stakeholder relationships.

The results of the data collection are summarized in Table 2 for the stakeholder salience dimension and in Table 3 for the strategic functionality dimension.

Table 2. Assessment of stakeholder salience dimension

\begin{tabular}{|c|c|c|c|c|c|c|c|}
\hline & Expectations & Exit costs & $\begin{array}{l}\text { Symbolic } \\
\text { relevance }\end{array}$ & & & Power & Total \\
\hline Weight & 0.2 & 0.3 & 0.1 & 0.2 & 0.2 & & 1 \\
\hline Shareholders & 3 & 4 & 1 & 1 & 4 & & 2.90 \\
\hline Human Resources & 4 & 5 & 4 & 3 & 5 & & 4.30 \\
\hline Labor Unions & 3 & 3 & 4 & 2 & 4 & & 3.10 \\
\hline Scientific Community & 4 & 3 & 5 & 1 & 4 & & 3.20 \\
\hline Financers & 4 & 2 & 1 & 1 & 4 & & 2.50 \\
\hline
\end{tabular}

The total calculated in the last column is a quantitative estimate of stakeholders' salience: the greater the value, the greater is the expected salience.

Likewise, we analyzed the second dimension: strategic functionality. In this case, the role that each stakeholder group has in the process of strategy realization is under evaluation. In other words, the analysis aims to understand the extent to which and the way in which stakeholders can influence the process of business model implementation. 
Table 3. Assessment of strategic functionality dimension

\begin{tabular}{|c|c|c|c|c|c|c|c|}
\hline & Corporate & $\begin{array}{l}\text { Economic } \\
\text { and } \\
\text { Financial }\end{array}$ & $\begin{array}{l}\text { Business } \\
\text { portfolio }\end{array}$ & Positioning & $\begin{array}{l}\text { Activities } \\
\text { and } \\
\text { Processes }\end{array}$ & Social & Total \\
\hline Weight & 0.05 & 0.2 & 0.2 & 0.05 & 0.3 & 0.2 & 1 \\
\hline Shareholders & 5 & 5 & 5 & 1 & 1 & 3 & 3.20 \\
\hline Human Resources & 2 & 1 & 3 & 5 & 5 & 4 & 3.45 \\
\hline Labor Unions & 4 & 1 & 1 & 1 & 2 & 5 & 2.25 \\
\hline Scientific Community & 3 & 1 & 2 & 3 & 3 & 5 & 2.80 \\
\hline Financers & 4 & 5 & 1 & 1 & 1 & 2 & 2.15 \\
\hline
\end{tabular}

The horizontal reading of the table allows the definition of the strategic relevance of each stakeholder group, both in synthetic and in analytic terms (with reference to each strategic choice category).

\subsection{Positioning Each Stakeholder Group within the Framework}

Considering the two dimensions identified (salience and strategic functionality), we can position the relevant stakeholders inside the framework, attributing them a measure for each dimension. These findings allow for the inductive development of a framework that provides a valuable answer to the research question and is translatable into new hypotheses for further research, as summarized in Figure 4. Attributing to each dimension a range from a minimum of 1 to a maximum of 5 (with a median value of 3), we can draw the specific relationship map, positioning each stakeholder group at the right position.

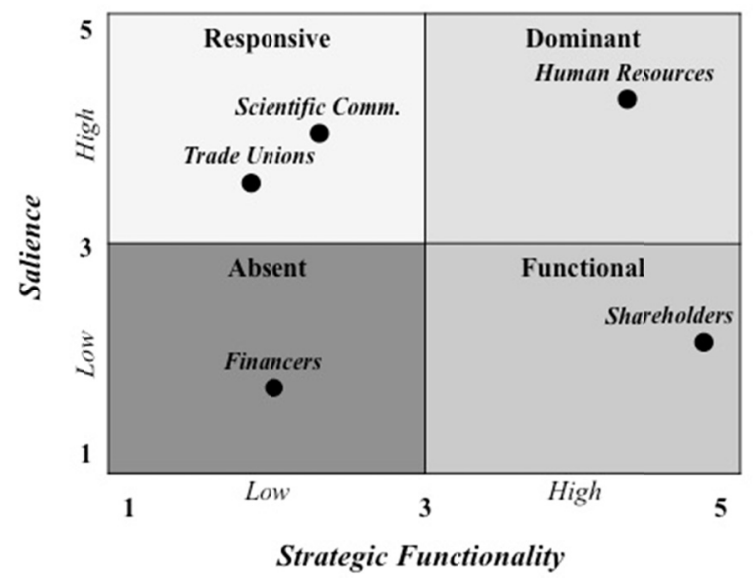

Figure 4. Stakeholder relationship framework assessment

The positioning within the matrix suggests some relevant features of firm-stakeholder relationships. Human resources (the 400 researchers of ScienceLab) is the most critical stakeholder group because it is characterized by both high strategic functionality and high salience. As for salience, the origins of this position are traceable to:

1) the high level of expectations related to the future benefits coming from the relationship with the firm;

2) the high exit costs, related to the specificity of researchers' intangible assets, such as competences, knowledge, and skills achieved over time and not easily usable in different context;

3) the power they have, highlighted by their strong organization and their quite easy access to information media.

As for the strategic functionality dimension, the position of human resources is justified by the relevance they have in influencing:

1) the positioning choices of the firm, strictly dependent on the specific competences and skills (i.e., research studies and results) achieved by researchers over time;

2) the organization structure and the operating processes;

3) the social impact of the firm's activity. 
The other stakeholder groups are characterized by the dominance of one of the two dimensions, or, as in the case of financers, by the marginal role of both of them. For instance, shareholders are characterized by high strategic functionality traceable to their role in influencing corporate, economic and business choices; the scientific community is characterized by high level of salience owing to the symbolic relevance of ScienceLab, the expectations of future benefits (i.e., research results), and the power the scientific community has in the relationship with the firm.

The different nature of the firm-stakeholder relationships, represented by the positions within the map, should guide the specific behavior of the firm toward each stakeholder category. In this sense, the framework responds to both descriptive and operative needs. Moreover, adopting a complementary perspective, the framework allows managers to understand and evaluate the risk associated with specific corporate choices.

This process occurred when BigPharma commenced evaluating the possibility of closing the center because of a cost reduction issue (i.e., the company owned another research center in the United States, and it intended to cut costs by centralizing all the research activities in that country). When in the evaluation process, the firm could not overlook the relationships with its relevant stakeholders and by the means of the framework suggested in this study, the firm arrived at the evaluation that, because of the critical position of human resources and scientific community, selecting the option of closing would have been too risky. Finally, BigPharma decided to maintain ScienceLab, while searching for a buyer interested in an acquisition that, even under disadvantageous economic conditions, would guarantee the retention of employees and continuation of oncology research that for many years characterized the center's activity. A new owner was found just a few years later.

\section{Discussion and Conclusions}

In recent years, scholars and practitioners have debated the importance of the integration of strategy with corporate sustainability (Baumgartner, 2014; Baumgartner \& Rauter, 2017; Engert \& Baumgartner, 2016; International Integrated Reporting Council, 2013; Rauter et al., 2017).

Within the wide sustainability borders, the set of relationships a firm has built with its stakeholders (Freeman, 1984; Mitchell et al., 1997) is a crucial topic, and the business model (Baden-Fuller \& Morgan, 2010; Chesbrough, 2010; Zott \& Amit, 2008) is, by its nature, the point of contact between a firm and its stakeholders, that is, between strategy and sustainability.

Starting from the relevance of the stakeholder-firm relationships and from the central role played by the business model, the study suggests a method to evaluate the nature of the relationships a firm has built with its stakeholders, analyzing the role played by each of them in the process of business model implementation and realization. The three-step method is built around a map, which through two dimensions (salience and strategic functionality) sheds light on the level of reactivity that each relevant stakeholder group has toward the evolution of the relationship with the firm and on the role the group plays in the process of business model realization.

Moreover, the following aspects are worth mentioning:

- The map is a synthesis tool that provides the analyst some insights to be deepened; in this sense, beyond the specific values and the positions obtained by different stakeholder groups, the evaluation process that has determined the values has a great relevance.

- The values and the specific positions within the map need to be continuously monitored, because they can change, even in significant ways, over the time.

This study suggests a framework that would help managers to constantly make strategic choices with the knowledge of the relevant stakes, with the comprehension of the role that different stakeholder groups could play in strategic choice implementation, and, most importantly, with the awareness of the risk associated with any strategic choice. Moreover, this method allows managers to constantly monitor and redesign the firmstakeholder relationships through business model choices.

This study proposes theoretical and practical contributions to the field. Theoretically, it contributes to the research on strategy-sustainability integration because, starting from the work of Mitchell et al. (1997), it adds a new perspective of analysis, strictly tied to the business model concept, and, practically, it presents a tool for managers who desire to better understand and manage both stakeholder relationships and business model choices. In particular, the suggested framework makes it possible to highlight a series of features that firm management may not be fully aware of, as well as opportunities and threats emerging from firm-stakeholder relationships whose value or significance may otherwise have been overlooked.

The adoption of such a model could help enterprises avoid strategic inertia, one of the biggest threats to their 
survival, since strategic inertia leads to resistance of strategic renewal outside the frame of current strategies and current stakeholder relationship settings (Huff, Huff, \& Thomas, 2007).

This study has several limitations, including the fact that it considers only one case study. Future research should consider a wider sample of cases, including organizations belonging to different industries and characterized by different levels of complexity. However, despite these limitations, the results of this preliminary study should be viewed as representing a first step in a broader area of research that aims to underline the value of improved knowledge of firm-stakeholder relationships and the role of business model choices in the process of sustainability-strategy integration.

This preliminary study contributes to the existing literature (Haslam, Tsitsianis, Andersson, \& Gleadle, 2015; Mitchell 1997) by adding a new dimension to Mitchell's (1997) study, stressing the role of stakeholders in influencing strategy realization. Simultaneously, the study suggests a managerial tool, useful to drive strategy execution effectively through a better understanding of the role played by each stakeholder (i.e., business model implementation).

\section{Acknowledgments}

This article is a result of the project BIT- Business Innovation \& Digital Tranformations (WP3 Sustainable Business Models), funded by Polo Scientifico Didattico Studi sull'Impresa (University of Verona), in cooperation with Fondazione Studi Universitari di Vicenza.

\section{References}

Abell, D. (1980). Defining the business: The starting point of strategic planning. Englewood Cliffs, NJ: Prentice Hall.

Adams, C. A. (2015). The international integrated reporting council: A call to action. Critical Perspectives on Accounting, 27, 23-28. https://doi.org/10.1016/j.cpa.2014.07.001

Amini, M., \& Bienstock, C. C. (2014). Corporate sustainability: An integrative definition and framework to evaluate corporate practice and guide academic research. Journal of Cleaner Production, 76, 12-19. https://doi.org/10.1016/j.jclepro.2014.02.016

Amit, R., \& Zott, C. (2001). Value creation in e-business. Strategic Management Journal, 22(6-7), 493-520. https://doi.org/10.1002/smj.187

Baden-Fuller, C., \& Morgan, M. S. (2010). Business model as models. Long Range Planning, 43, 156-171. https://doi.org/10.1016/j.lrp.2010.02.005

Baumgartner, R. J. (2009). Organizational culture and leadership: Preconditions for the development of a sustainable corporation. Sustainable Development, 17(2), 102-113. https://doi.org/10.1002/sd.405

Baumgartner, R. J. (2010). Nachhaltigkeitsorientierte Unternehmensführung: Modell, Strategien und Managementinstrumente (Sustainable business management: Framework, strategies and management instruments). Munich, Germany: Rainer Hampp Verlag.

Baumgartner, R. J. (2014). Managing corporate sustainability and CSR: A conceptual framework combining values, strategies and instruments contributing to sustainable development. Corporate Social Responsibility and Environmental Management, 21(5), 258-271. https://doi.org/10.1002/csr.1336

Baumgartner, R. J., \& Rauter, R. (2017). Strategic perspectives of corporate sustainability management to develop a sustainable organization. Journal of Cleaner Production, 140, 81-92. https://doi.org/10.1016/j.jclepro.2016.04.146

Beattie, V., \& Smith, S. J. (2013). Value creation and business models: Refocusing the intellectual capital debate. British Accounting Review, 45(4), 243-254. https://doi.org/10.1016/j.bar.2013.06.001

Berg, B. L. (2009). Qualitative research methods of the social sciences (7th ed.), Boston, MA: Allyn \& Bacon.

Bocken, N. M., Short, S. W., Rana, P., \& Evans, S. (2014). A literature and practice review to develop sustainable business model archetypes. Journal of Cleaner Production, 65, 42-56. https://doi.org/10.1016/j.jclepro.2013.11.039

Boons, F., \& Lüdeke-Freund, F. (2013). Business models for sustainable innovation: State-of-the-art and steps towards a research agenda. Journal of Cleaner Production, 45, 9-19. https://doi.org/10.1016/j.jclepro.2012.07.007

Bowie, N. (1988). The moral obligations of multinational corporations. In S. Luper-Foy (Ed.), Problems of 
international justice (pp. 97-113). Boulder, CO: Westview Press.

Bowman, C. (2008). Generic Strategies: A substitute for thinking? Ashridge Journal, Spring, 1-6.

Burke, L., \& Logsdon, J. M. (1996). How corporate social responsibility pays off. Long range planning, 29(4), 495-502. https://doi.org/10.1016/0024-6301(96)00041-6

Chesbrough, H. W. (2007). Business model innovation: It's not just about technology anymore. Strategy \& leadership, 35(6), 12-17. https://doi.org/10.1108/10878570710833714

Chesbrough, H. W. (2010). Business model innovation: Opportunities and barriers. Long Range Planning, 43, 354-363. https://doi.org/10.1016/j.lrp.2009.07.010

Clarkson, M. E. (1995). A stakeholder framework for analyzing and evaluating corporate social performance. Academy of Management Review, 20(1), 92-117. https://doi.org/10.5465/amr.1995.9503271994

Cornell, B., \& Shapiro, A. C. (1987). Corporate stakeholders and corporate finance. Financial Management, 16(1), 5-14.

Dentchev, N. A. (2004). Corporate social performance as a business strategy. Journal of Business Ethics, 55(4), 395-410. https://doi.org/10.1007/s10551-004-1348-5

Denzin, N. K. (1978). The research act: A theoretical introduction to sociological methods. New York, NY: McGraw-Hill.

Doz, Y. L., \& Kosonen, M. (2010). Embedding strategic agility. A leadership agenda for accelerating business model renewal. Long Range Planning, 43, 370-382. https://doi.org/10.1016/j.lrp.2009.07.006

Duarte, A. P., Martins, P., \& Alexandre, J. (2008). Pro-active behaviour induction by integration of sustainability in business strategic management: INOVE project case study. Journal of Cleaner Production, 16, 1127-1132. https://doi.org/10.1016/j.jclepro.2007.05.005

Eisenhardt, K. M. (1989). Building theories from case study research. Academy of Management Review, 14(4), 532-550. https://doi.org/10.5465/amr.1989.4308385

Eisenhardt, K. M., Graebner, M. E., \& Sonenshein, S. (2016). Grand challenges and inductive methods: Rigor without rigor mortis. Academy of Management Journal, 59, 1113-1123. https://doi.org/10.5465/amj.2016.4004

Engert, S., \& Baumgartner, R. J. (2016). Corporate sustainability strategy-bridging the gap between formulation and implementation. Journal of Cleaner Production, 113, 822-834. https://doi.org/10.1016/j.jclepro.2015.11.094

Engert, S., Rauter, R., \& Baumgartner, R. J. (2016). Exploring the integration of corporate sustainability into strategic management: A literature review. Journal of Cleaner Production, 112, 2833-2850. https://doi.org/10.1016/j.jclepro.2015.08.031

Faulkner, D., \& Bowman, C. (1995). The essence of competitive strategy. Hemel Hempstead, United Kingdom: Prentice Hall.

Fiegenbaum, A., Hart, S., \& Schendel, D. (1996). Strategic reference point theory. Strategic Management Journal, 17(3), 219-235. https://doi.org/10.1002/(SICI)1097-0266(199603).

Freeman, R. E. (1984). Strategic management: A stakeholder approach. Boston, MA: Pitman.

Freeman, R. E. (1994). The politics of stakeholder theory: Some future directions. Business Ethics Quarterly, 4(4), 409-421. 10.2307/3857340

Ghaziani, A., \& Ventresca, M. J. (2005). Keywords and cultural change: Frame analysis of business model public talk, 1975-2000. Sociological Forum, 20(4), 523-559. https://doi.org/10.1007/s11206-005-9057-0

Håkansson, H., \& Sneotha, I. (1995). Developing relationships in business networks. London, United Kingdom: Routledge.

Haslam, C., Tsitsianis, N., Andersson, T., \& Gleadle, P. (2015). Accounting for business models: Increasing the visibility of stakeholders. Journal of Business Models, 3(1). https://doi.org/10.5278/ojs.jbm.v3i1.1066

Hemingway, C. A., \& Maclagan, P. W. (2004). Managers' personal values as drivers of corporate social $\begin{array}{lllll}\text { responsibility. Journal of Business } & \text { Ethics, } & 50(1), & 33-44 .\end{array}$ https://doi.org/10.1023/B:BUSI.0000020964.80208.c9

Hofer, C. W., \& Schendel, D. (1978). Strategy formulation: Analytical concepts. St Paul, MN: West Publishing. 
Huff, J. O., Huff, A. S., \& Thomas, H. (2007). Strategic renewal and the interaction of cumulative stress and inertia. Strategic Management Journal, 13(1), 55-75. https://doi.org/10.1002/smj.4250131006

International Integrated Reporting Council. (2013). Integrated Reporting Framework. London, United Kingdom: Author.

Jin, Z., \& Bai, Y. (2011). Sustainable development and long-term strategic management: Embedding a long-term strategic management system into medium and long-term planning. World Future Review, 3(2), 49-69. https://doi.org/10.1177\%2F194675671100300208

Lambert, S. C., \& Davidson, R. A. (2013). Applications of the business model in studies of enterprise success, innovation and classification: An analysis of empirical research from 1996 to 2010. European Management Journal, 31, 668-681. https://doi.org/10.1016/j.emj.2012.07.007

Lankoski, L. (2007). Corporate responsibility activities and economic performance: A theory of why and how they are connected. Business Strategy and the Environment 17(8), 536-547. https://doi.org/10.1002/bse.582

Lozano, R., Ceulemans, K., Alonso-Almeida, M., Huisingh, D., Lozano, F. J., Waas, T.,... \& Hugé, J. (2015). A review of commitment and implementation of sustainable development in higher education: Results from a worldwide survey. Journal of Cleaner Production, 108, 1-18. https://doi.org/10.1016/j.jclepro.2014.09.048

Magretta, J. (2002). Why business models matter. Harvard Business Review, 80(5), 86-92.

McKinsey \& Company. (2014). McKinsey global survey results: Sustainability’s strategic worth. Retrieved from. http://www.mckinsey.com/insights/sustainability/sustainabilitys_strategic_worth_mckinsey_global_survey_ results.

McNamara, G., Deephouse, D. L., \& Luce, R. A. (2003). Competitive positioning within and across a strategic group structure: The performance of core, secondary, and solitary firms. Strategic Management Journal, 24(2), 161-181. https://doi.org/10.1002/smj.289

McWilliams, A., \& Siegel, D. S. (2011). Creating and capturing value: Strategic corporate social responsibility, resource-based theory, and sustainable competitive advantage. Journal of Management, 37(5), 1480-1495. https://doi.org/10.1177\%2F0149206310385696

Mitchell, R. K., Bradley R. A., \& Donna J. W. (1997). Toward a theory of stakeholder identification and salience: Defining the principle of who and what really counts. Academy of Management Review, 22(4), 853-886. https://doi.org/10.5465/amr.1997.9711022105

Moggi, S. (2017). Focus groups in social accounting as a stakeholder engagement tool. In D. Crowther, \& L. Lauesen (Eds.), Handbook of Research Methods in Corporate Social Responsibility (pp. 364-376). Cheltenham, United Kingdom: Edward Elgar Publishing.

Näsi, J. (1995). What is stakeholder thinking? A snapshot of a social theory of the firm. In J. Näsi, \& S. Näsi (Eds.), Management Tensions and Configurations, Papers on Strategic Management Issues in the Stakeholder Society (pp. 15-29). (Reports from the School of Business and Economics, University of Jyväskylä; No. 30). Jyväskylä, Finland: University of Jyväskylä.

Osterwalder, A., Pigneur, Y., \& Tucci, C. L. (2005). Clarifying business models: Origins, present, and future of the concept. Communications of the Association for Information Systems, 16(1), 1.

Patton, M. Q. (2002). Qualitative research and evaluation methods. London, United Kingdom: Sage

Porter, M. E. (1980). Competitive strategy. New York, NY: Free Press.

Rauter, R., Jonker, J., \& Baumgartner, R. J. (2017). Going one's own way: Drivers in developing business models for sustainability. Journal of Cleaner Production, 140, 144-154. https://doi.org/10.1016/j.jclepro.2015.04.104

Richardson, J. (2008). The business model: An integrative framework for strategy execution. Strategic Change, 17(5/6), 133-144. https://doi.org/10.1002/jsc.821

Ries, A., \& Trout, J. (2001). Positioning: The battle for your mind. New York, NY: McGraw Hill.

Sherman, B. (2001). Ethnographic interviewing. In P. Atkinson, A. Coffey, S. Delamont, J. Lofland, \& L. Lofland (Eds.) Handbook of ethnography (pp. 369-379). London, United Kingdom: Sage.

Simanis, E.,\& Hart, S. (2009). Innovation from the inside out. MIT Sloan Management Review 50(4), 77-86.

Solinas G., \& Vernizzi S. (2011). The qualitative tools of strategic analysis. In B. A. Zanoni (Ed.), Strategic 
analysis: Processes and tools (pp. 34-48). New York, NY: Routledge.

Stead, J. G., \& Stead, E. (2000). Eco-enterprise strategy: Standing for sustainability. Journal of Business Ethics, 24(4), 313-329. https://doi.org/10.1023/A:1006188725928.

Suchman, M. C. (1995). Managing legitimacy: Strategic and institutional approaches. Academy of Management Review, 20, 571-610. https://doi.org/10.5465/amr.1995.9508080331

Weber, Y., \& Tarba, S. Y. (2014). Strategic agility: A state of the art. California Management Review, 56(3), 5-12. https://doi.org/10.1525\%2Fcmr.2014.56.3.5

Windsor, D. (1992, July). Stakeholder management in multinational enterprises. In B. Agle, \& C. VanSandt (Eds.), Proceedings of the International Association for Business and Society, IASB, (Vol. 3, pp. 241-255).

World Commission on Environment and Development. (1987). Our common future. Oxford, United Kingdom: Oxford University Press.

Yin, R. (1984). Case study research: design and methods. Beverly Hills, CA: Sage.

Zott, C., \& Amit, R. (2008). The fit between product market strategy and business model: Implications for firm performance. Strategic Management Journal, 29(1), 1-26. https://doi.org/10.1002/smj.642

Zott, C., Amit, R., \& Massa, L. (2011). The business model: Recent developments and future research. Journal of Management, 37, 1019-1042. https://doi.org/10.1177\%2F0149206311406265

\section{Copyrights}

Copyright for this article is retained by the author(s), with first publication rights granted to the journal.

This is an open-access article distributed under the terms and conditions of the Creative Commons Attribution license (http://creativecommons.org/licenses/by/4.0/). 